\title{
THE EICHMANN TRIAL ON EAST GERMAN TELEVISION
}

\section{ON (NOT) REPORTINGABOUTA TRANSNATIONAL MEDIA EVENT}

\author{
Judith Keilbach \\ Utrecht University \\ Department of Media and Culture Studies \\ Muntstraat 2A \\ 3512 EV Utrecht \\ The Netherlands \\ J.Keilbach@uu.nl
}

\begin{abstract}
This paper discusses the Eichmann trial (1961) as a transnational media event. It describes on the one hand the co-operation of different institutions that facilitated the trial's filming as well as the worldwide distribution of the footage. On the other hand it draws on East and West German television programs to show how the GDR used the Eichmann trial to campaign against the FRG. Examples from the East German Der schwarze Kanal and the West German Die rote Optik illustrate the reciprocal monitoring and commenting of the other side's television program. The case of the Eichmann trial points at a significant role of broadcast media during the Cold War. Television advocated the respective political system with particular programs denigrating the other side which sometimes resulted in strong reactions.
\end{abstract}

Keywords: Transnational, Media event, Cold War, West/East Germany

The trial against Adolf Eichmann opened on April 11, 1961 and was one of the first global media events on television. With reports on the news, current affairs or special programs in 38 countries the trial was believed to be covered world-wide. ${ }^{1}$ A year later, when it was announced that the broadcast of the four-month proceedings won a Peabody Award, a press release praised it as "an important step forward in the development of international television" acclaiming that "the project transcended national boundaries, cultures and ideologies."

Originally meant to highlight the universal significance of the war crime trial this statement is a perfect starting point for a closer examination of the television coverage of the Eichmann trial. Taking the statement literally I will argue that while it is true that the trial footage transcended national borders it did not overcome "national ideologies". Quite the contrary: the Eichmann trial facilitated an intensification of ideological conflicts between East and West Germany as examples from the Deutsche Fernsehfunk will show. After a brief overview of the trial's television set up I will refer to a number of East German television programs to exemplify how East Germany used the Eichmann trial to discredit the West German Government. ${ }^{3}$

\footnotetext{
Television Age, 7 August 1961, p. 27.

2 Israel State Archives, Fruchtman Collection, F 3264/2, press release by Capital Cities Broadcasting Corporation, 18 April 1962.

3 Although East German television is well archived at the Deutsches Rundfunkarchiv Babelsberg only a few programs about the Eichmann trial are kept. Unfortunately the DRA didn't grant permission to publish any of its documents and programs.
} 


\section{Setting Up a Transnational Television Event}

Eichmann, the chief logistics organizer of mass deportations and the Holocaust, was tried in Jerusalem. Since television did not yet exist in 1961 in Israel the Israeli government contracted Capital Cities - an independent television company from the US - to provide the images. The company was obligated to record the whole trial on videotape and to make the footage available to all television stations and newsreel companies. Television producer Milton Fruchtman who initiated the whole enterprise had 4 television cameras and 2 Ampex videotape recorders shipped to Jerusalem. He recruited Israeli cameramen and hired television technicians from Great Britain and the US as well as Leo Hurwitz, an American documentary filmmaker and former CBS news director who was blacklisted in the 1950s and was denied (credited) employment ever since.

Each day correspondents could select 3 minutes of the recorded trial footage to be copied and sent home to their stations or news agencies. The East German Deutsche Fernsehfunk was one of the broadcasters of the Eastern Bloc that made use of this offer. For an extra fee the West German NDR, the American networks and the British commercial broadcaster ITV even got one hour each day. ${ }^{4}$ For these major users two copies were made during the trial's lunch break, with one of them air freighted to New York, the other one to London.

Since the Ampex machines were configured according to the American technical standard the videotapes for Europe had to be transferred to the European standard line resolution before they were sent to the television stations in London and Hamburg. In the US the tapes were picked up at the airport, copied and then the three networks competed in being the first to get the trial footage on the air. This race made it even into the newspapers with Variety trying to determine which network "got a 'beat' on the first tapes of the Eichmann trial" on the morning of April 12th. ${ }^{5}$ Under the headline "Eichmann, Gagarin: Instant TV" the article describes how "a Russian Cosmonaut and a German butcher doing their stuff on the same Tuesday (11) has been more than enough to throw networks and indies into the most fantastic and frenetic drive for news yet". ${ }^{6}$ The Eichmann trial proved - together with Gagarin's space flight television's ability for immediate reporting of global news events.

Although the television coverage of the Eichmann trial was no live transmission it strove to be as immediate as possible. The particular media constellation of that time - the combination of video, television and jet planes allowed for an anticipation of the boundless possibilities of satellite technology yet to come. More than a year before television started to use satellite technology for relaying live images across the Atlantic the images from Jerusalem foreshadowed satellites' "capacity to craft a 'global now". ${ }^{7}$

\section{Broadcasting Across the Inner German Boarder}

Although Capital Cities provided national television stations and networks with its trial footage the project did indeed transcend national boundaries. Apart from the particular setup that required transnational cooperation one could argue from a technological perspective that potentially broadcasting can always overcome national boarders - as the case of East and West German television illustrates.

Setting up television after the war was in Germany a competitive matter since both German states competed for being the fist one to broadcast television. Given the political and ideological conflicts between the German Democratic

\footnotetext{
${ }^{4}$ Variety reported in detail about the difficult negotiations with the US networks. See Variety, 25 January, 1 February, 15 February and 1 March

1961.

${ }^{5}$ Variety, 19 April 1961

${ }^{6}$ Ibid.

7 Lisa Parks, Cultures in Orbit: Satellites and the Televisual, Duke Univ. Press, 2005, p. 22.
} 
Republic (GDR) and the Federal Republic of Germany (FRG) this race was not only about proving ones own technological superiority; it was also about occupying the wavelengths that the European frequency plan allocated to German television. ${ }^{8}$ Starting around the same time television in East and in West Germany at first had a limited range. Over the course of time, however, both countries built television transmitters close to the inner German boarder to reach viewers also in the other part of the country. ${ }^{9}$

Not only did ordinary viewers watch the broadcasts from across the Iron Curtain, they were also monitored by television itself. ${ }^{10}$ The other side's programming even provided footage for political television magazines. The West German Die rote Optik and the East German Der schwarze Kanal for example both displayed fragments of programs from television 'over there' to criticize their respective ideological implications. ${ }^{11}$ In preparation for these political magazines the television flow of the other side was recorded on videotape and relevant sequences were transcribed. Based on these transcripts excerpt were selected that Karl-Eduard von Schnitzler, host of the East-German Schwarze Kanal, and Thilo Koch, host of the West-German Rote Optik, could present to their viewers with sardonic comments.

\section{Warming Up for the Eichmann Trial}

In 1961 these two programs were part of a fierce dialogue about the Nazi past as they both picked up the other side's coverage of the Eichmann trial. In what follows I briefly summarize how East Germany dealt with the Eichmann trial and provoked West Germany's response to show that the coverage was highly ideological - despite its universal topic.

When in May 1960 Israel's Prime Minister Ben-Gurion announced the capture of Adolf Eichmann his message caused quite a stir. Relief about having found one of the most wanted Nazis mixed with legal concerns since Israel's intelligence had kidnapped Eichmann in Argentina. In the first weeks after Eichmann's capture the question of jurisdiction dominated the public discussion in both German states. While the East German newspaper Neues Deutschland immediately alleged that the FRG asked for Eichmann's extradition to set him free ${ }^{12}$ guests of the West German talk show Der internationale Frühschoppen (an adaption of Meet the Press) discussed the FRG's possible reactions and addressed questions such as: Should the Adenauer government demand Eichmann's extradition? Can an Israeli court be objective? Should Eichmann be tried by an international tribunal? ${ }^{13}$

The East German Schwarze Kanal used this discussion to attack the FRG's permissive attitude towards former Nazis. In his show on June 13th, 1960 Karl-Eduard von Schnitzler presents an excerpt from Der internationale Frühschoppen in which a journalist suggests to bring Eichmann to a West-German court to which host Werner Höfer subsequently agrees. ${ }^{14}$ Schnitzler comments on this fragment by pointing to the "more than 1000 " West-German judges who are former Nazis. Naming two of them he states that a West-German court would clear Eichmann of all crimes and insinuates that such a verdict of not guilty is how the guests on Höfer's talk show (as well as all West-German politicians) want to handle the case.

\footnotetext{
${ }^{8}$ Heather Gumbert, 'Split Screens? Television in East Germany, 1952-89,' in Karl Christian Führer and Corey Ross, eds., Mass Media, Culture and Society in Twentieth-Century Germany, Palgrave Macmillan, 2006, 146-164, p. 148. Claudia Dittmar, Feindliches Fernsehen: Das DDR-Fernsehen und seine Strategien im Umgang mit dem westdeutschen Fernsehen, transcript, 2010, p. 65.

9 Dittmar, 2010, p. 79f.

${ }^{10}$ For more about the East German reception of West German television see Michael Meyen, ,Die ARD in der DDR,' Aus Politik und Zeitgeschichte 20/2010, 28-34

${ }^{11}$ See for example Matthias Steinle, Vom Feindbild zum Fremdbild: Die gegenseitige Darstellung von BRD und DDR im Dokumentarfilm, UvK, 2003, p. $165 f$

12 Neues Deutschland, 26 May 1960.

13 Excerpts of the Der international Frühschoppen are included in the Der schwarze Kanal from 13 June 1960.

14 During the 'Third Reich' Werner Höfer had written propaganda articles and was himself a former Nazi. The GDR discovered his past in 1962, but only in 1987 after a critical article in the West German Der Spiegel (14 December 1987) was he removed from Der international Frühschoppen.
} 
Schnitzler's reasoning was in accordance with the GDR's campaign against the Blutrichter, i.e. the hanging judges of the Nazi time who were now backing the Adenauer regime..$^{15}$ In the FRG these accusations came neither as a surprise nor did Schnitzler's attack cause any concern since the Blutrichter campaign had started already in 1959. Few months later however, the situation had changed. In July 1960 the Foreign Ministries of the USSR, Poland, Hungary, Czechoslovakia, Romania and the GDR had agreed upon making the most of the Eichmann trial to fight West Germany's "neo-fascism". ${ }^{16}$ The GDR took the lead and searched the archives to find incriminating documents about West German politicians and their relationship with Eichmann.

The campaign that resulted from this research zeroed in on Hans Globke, the director of Adenauer's Chancellery. During the Third Reich Globke was a high ranking civil servant at the Reichsinnenministerium and (co-)author of bills and regulations concerning the Nuremberg Laws (1935). Amongst others he had composed the regulation that all German Jews had to be identifiable by a Jewish name (1938). After the war Globke exculpated himself by stating that he was not the sole author, that his regulations prevented the Jews from worse and that he backed the "catholic resistance". ${ }^{17}$

East Germany used the upcoming Eichmann trial to campaign against Globke. The attacks were accurately planned: In September 1960 the Central Committee of the SED started to organize press conferences to present documents about Globke's past. News items about Globke and interviews with his "Jewish victims" were scheduled on television and the filmmaker Walter Heynowski started to work on his documentary Aktion J. that portrays Globke's career. ${ }^{18}$

Closely monitoring the GDR's media output West German television started to pick up these stories. For example on December 19, 1960 Die rote Optik referred to an East German television drama about Eichmann and discusses in this context also the role of Hans Globke. Thilo Koch, the program's host, criticizes Adenauer's staffing policy explicitly, stating that he had overlooked too generously the former activities of some of his staff members. From all we know, Koch says, Globke was complicit in the anti-Semitic policy of the Nazi state. ${ }^{19}$ Although harshly disapproving the GDR's exploitation of the Eichmann case Die rote Optik looked thus into the GDR's accusations (and partly agreed with them).

\section{Covering the Eichmann Trial}

When the Eichmann trial started the GDR increased the pressure on the Adenauer government. Friedrich Karl Kaul, an East German lawyer, even traveled to Jerusalem using the international attention that the Eichmann trial created to accuse Globke publically. In accordance with his government Kaul organized a press conference where he presented documents about Globke's involvement in mass murders.

East German television used the Eichmann trial also to attack Globke. On April 11, 1961 the news show Aktuelle Kamera broadcast a news item about the trial's opening day stating that while Eichmann is indicted for mass murder Globke, the author of the laws that facilitated these crimes, holds an influential position in the West German government. „Adolf Eichmann steht vor Gericht“, the voice over says, „,doch viele seiner Komplicen und Auftraggeber leben heute noch in der Bundesrepublik. Nicht wenige haben heute wieder Macht und Einfluß im Staate Adenauers.

\footnotetext{
15 In the context the Blutrichter campaign the GDR published booklets with the names of about 1000 judges and prosecutors and distributed them in the FRG.

16 Michael Lemke, ,Instrumentalisierter Antifaschismus und SED-Kampagnenpolitik im deutschen Sonderkonflikt 1960-1968,' in Jürgen Danyel, ed., Die geteilte Vergangenheit: Zum Umgang mit Nationalsozialismus und Widerstand in beiden deutschen Staaten, Akademie Verlag, 1995, 61-68, p. 69.

17 For more about Globke see Jürgen Bevers, Der Mann hinter Adenauer, Christoph Links Verlag, 2009. Erik Lommatzsch, Hans Globke (1898-

1973): Beamter im Dritten Reich und Staatssekretär Adenauers, Campus, 2009.

18 Bundesarchiv, Berlin, DY 30/IV 2/2.028/21.

19 Staatsarchiv, Hamburg, Bestand NDR, 621-1/144 177, Manuskript Die Rote Optik (aired 19 December 1960), p. 9.
} 
Referring to the Bavarian city Fürth the voiceover mentions that only 50 Jews had survived, "die anderen waren gemäß den Nürnberer [sic.] Gesetzen isoliert und geächtet worden - das war das Werk des Dr. Globke. Und dann waren sie in die Vernichtungslager gebracht worden, wo Adolf Eichmann das Werk des Dr. Globke fortsetzte und vollendete". .20

By presenting Eichmann as subordinate who implemented the Nuremberg laws that Globke created the Aktuelle Kamera accuses Adenauer's assistant of murder of the city's Jewish population.

Programs about Eichmann and Globke were also scheduled for the next day, however Gagarin's flight mixed up the timetable and led to a number of special reports. Amongst the programs that were not rescheduled was the talk show Treffpunkt Berlin that was hosted by Karl-Eduard von Schnitzler. Despite the euphoria about the Soviet achievement the live show didn't change its originally planned topic: the Eichmann trial. After a short, pathos-laden salute to Gagarin Schnitzler asks his guests - amongst them the above mentioned lawyer Friedrich Karl Kaul - what they think about Globke and the fact that he hold an important position in the FRG despite his involvement in Nazi crimes. Amongst others the guests discuss how Globke could be brought to trial and state that the West German government instructed Eichmann's lawyer to prevent him from testifying against Globke. Similar to the Aktuelle Kamera a day earlier, Treffpunt Berlin exploits the trial to accuse Globke of initiating Eichmann's actions. ${ }^{21}$

A week later East German television aired Aktion J., a documentary by Walter Heynowski that uses a tricky montage of documents and archival photographs to circumstantiate Globke's responsibility for mass murder. ${ }^{22}$ The film caused a direct response on West German television since the NDR requested an interview with Globke about his function during the 'Third Reich'. ${ }^{23}$ Broadcast on April 28, 1961 in Die rote Optik the interview was quickly picked up by the East German Schwarze Kanal.

But while in the original interview Globke refuted most of the film's assumptions Der schwarze Kanal selects excerpts to prove the accuracy of the GDR's accusations. Karl-Eduard von Schnitzler introduces the fragment by pointing to Globke's gradual confession over the past years before he shows Globke admitting that he had written the legal commentary to the Reich Citizenship Law and co-authored a regulation that all German Jews had to be identifiable by a Jewish name. Taken out of context these two statements were edited seamlessly together, suggesting that Globke made a public confession. The excerpt ends with Globke referring to Heynowski's film Aktion J. which implies the power of the film's evidence. Schnitzler's comments leave no doubt that Globke had to admit his crimes due to the GRD's inquiries and publications.

\section{Maintaining Ideological Boundaries}

The reciprocal commenting on East and West German television attests not only that the Eichmann trial facilitated a discussion beyond boarders; it also shows that the GDR was hardly interested in illuminating Eichmann's crimes. ${ }^{24}$ It is not by accident that East German television presented little trial footage from Jerusalem. Many of the still existing television items linked to the Eichmann trial relied either on documents and statements about Globke that were produced in the GDR or on West German television excerpts.

\footnotetext{
20 Deutsches Rundfunkarchiv Babelsberg, Manuskript Aktuelle Kamera (aired 11 April 1961).

21 In 1963 the GDR put Globke in absentia on trial for mass murder. East German television covered the proceedings in special reports.

22 An analysis of Aktion $\mathrm{J}$ and the film's use of documents can be found in Tobias Ebbrecht-Hartmann, 'Anklage und Archiv: Archivmaterial und seine Anordnung in Walter Heynowskis Aktion J - Ein Film der Beweise (1961),' in Bastian Blachut, Imme Klages, Sebastian Kuhn, eds., Nachkriegskino in Deutschland, Edition text + kritk, forthcoming.

23 Staatsarchiv, Hamburg, Bestand NDR, 621-1/144 177

24 The reasons for the GDR's disinterest are manifold, amongst others its pragmatic integration of former (minor) Nazis, its conception of Jewish victims who were deemed to not having fought back, its anti-Jewish purging of 'cosmopolitans 'in the 1950s and its anti-Zionism. See e.g. Jeffrey Herft, Divided Memory: The Nazi Past in the Two Germanys, Harvard Univ. Press, 1997.
} 
Most of all the East German programs demonstrate how the GDR exploited the Eichmann trial to campaign against the West Germany government. By revealing the Nazi past of Adenauer's director of Chancellery the GDR did not just strive for Globke's resignation but also aimed at damaging West Germany's international reputation and weakening its integration in the NATO alliance. This strategy however, accepted increasing ideological tensions. By claiming that West Germany is a threat to the world the GDR offended those West Germans who questioned their government's handling of former Nazis. At the same time the GDR's attacks played into the hands of conservative West Germans who accused those critical West Germans of being communists. ${ }^{25}$ As the broadcasts about the Eichmann trial transcended national boarders they fueled the ideological divide between East and West Germany.

\section{B i ograph y:}

Judith Keilbach is Assistant Professor of Television Studies in the Media and Culture Studies Department of Utrecht University (Netherlands) with a PhD in Film Studies from the Freie Universität Berlin. Her research focuses on television history and theory, the relation between media technology and historiography, archives, media events and the transformations of television. Her publications about the representation of National Socialism and the Holocaust appeared amongst others in New German Critique and History \& Theory. She is author of Geschichtsbilder und Zeitzeugen ('Historical Images and Witnesses') and co-editor of Grundlagentexte zur Fernsehwissenschaft and Die Gegenwart der Vergangeheit. Her current research project focuses on the Eichmann trial as transnational media event. 